\title{
Intermittency in Wind Energy and Emissions from the Electricity Sector: Evidence from 13 Years of Data
}

\author{
Dilek Uz * and Callista Chim
}

Department of Economics, University of Nevada, Reno, NV 89557, USA; cchim@nevada.unr.edu

* Correspondence: dilekuz@unr.edu

\begin{abstract}
Renewable subsidies and mandates currently play a central role in the environmental and energy policy in the United States, one of the world's top greenhouse gas emitters. Therefore, accurately estimating the environmental benefits from wind energy is key to evaluating the existing policies and setting future directions and has been studied within a growing body of the literature. However, most of the existing studies do not take the intermittency into account, and the small number of studies that do only study a relatively short time period limiting the extent to which they can be informative within different ranges of wind generation capacity. In this paper, we present the first estimates of the environmental benefits of wind energy generation using a dataset that spans well over a decade. Specifically, we use 13 years of hourly and sub-hourly data to estimate the causal effect of wind generation and its intermittency on $\mathrm{CO}_{2}, \mathrm{NO}_{x}$, and $\mathrm{SO}_{2}$ emissions from the electricity sector in Texas. Additionally, we compared the full sample results to those from sub-samples where the dataset is divided into subgroups based on wind output level. We found that while wind generation clearly has a statistically significant negative marginal effect on all pollutants we studied, the marginal effect of intermittency varies across different wind output levels in a highly irregular way. Our findings suggest that conducting pooled analyses has the potential to mask the irregularity in the variation of the effect of intermittency in wind generation across different wind output levels.
\end{abstract}

Citation: Uz, D.; Chim, C.

Intermittency in Wind Energy and

Emissions from the Electricity Sector:

Evidence from 13 Years of Data.

Sustainability 2022, 14, 2242. https://

doi.org/10.3390/su14042242

Academic Editor: Pablo García

Triviño

Received: 24 December 2021

Accepted: 4 February 2022

Published: 16 February 2022

Publisher's Note: MDPI stays neutral with regard to jurisdictional claims in published maps and institutional affiliations.

Copyright: () 2022 by the authors. Licensee MDPI, Basel, Switzerland. This article is an open access article distributed under the terms and conditions of the Creative Commons Attribution (CC BY) license (https:// creativecommons.org/licenses/by/ $4.0 /)$.

Keywords: emissions; electricity sector; wind generation; intermittency

JEL Classification: Q42, Q48, Q53, Q55

\section{Introduction}

Wind generation capacity in the United States has grown rapidly in the past two decades due to the precipitous decline in costs as well as financial incentives and state level mandates for renewable energy playing a central role in US environmental policy [1,2]. Consistently, annual electricity generation from wind energy increased from 6 billion $\mathrm{kWh}$ ( $0.1 \%$ of total) in 2000 to 338 billion kWh ( $8.4 \%$ of total) in 2020 in the US [3]. Since the environmental benefits are cited as the main justification for allocating public funds to incentivize renewable energy sources, accurately measuring these environmental benefits is key for evaluating existing policies as well as setting future policy directions. For this reason, this topic has been the focus of a recently growing strand of economic and engineering studies. This paper extends the literature by significantly expanding the time period and hence the scope of wind generation capacities within which this subject is studied and by using more flexible functional forms in the estimation models allowing for an additional source of heterogeneity in the estimated effect.

Fixed costs make up the majority of the total cost of operating a wind farm, and as there are no fuel costs, the marginal operating cost is nearly negligible [4]. Furthermore, each unit of generation receives a production tax credit from the federal government; hence, wind energy generators have the incentive to produce whenever possible, including 
the periods of time when the wholesale market price is zero or even negative (except when there is curtailment due to transmission constraints which constitutes a very small portion of wind generation). This implies that wind turbines displace fossil-fuel burning generators which account for $25 \%$ of greenhouse gas emissions in the US, one of the world's top greenhouse gas emitters [5]. Meanwhile, an important challenge associated with this dramatic transformation in the electricity system is that renewable sources are highly intermittent. The need to instantaneously match generation (supply) and load (demand) in the absence of large-scale storage in the grid necessitates dispatchable sources such as natural gas and coal plants to ramp up and down more frequently in the face of stochastic wind and solar generation. Ramping up and down production is fuel intensive and has the potential to increase per-unit emissions from fossil-fuel burning generators, limiting the environmental benefits of renewable energy technologies [6]. On the other hand, as explained in [7], this additional need for flexibility can force the system operator to dispatch more flexible natural gas generators at a higher intensity. While this can imply less generation from coal and hence less emissions, it is possible that operating at lower output levels can cause the coal burning units to have higher heat and emissions rate [8]. The net effect of all these, sometimes competing, mechanisms are not clear ex ante without solving a complex dynamic grid optimization problem using a detailed dispatch model.

An alternative route would be an ex post econometric data analysis, which is what this paper takes. Specifically, using 13 years of hourly and sub-hourly data from the Electric Reliability Council of Texas (ERCOT), we estimated the causal effects of wind generation and its intermittency on $\mathrm{CO}_{2}, \mathrm{SO}_{2}$, and $\mathrm{NO}_{x}$ emissions from the electricity sector. ERCOT is an ideal setting for such a study as it has a high level of wind power penetration with $25 \mathrm{GW}$ of installed wind capacity as of October 2020 (82 GW total) [9]. This was also confirmed by our own calculations compiled using EIA data presented in Table 1. Based on the data presented here, in 2007, the share of wind generation constituted about $2.9 \%$ of the total generation, while in 2019 , this number was about $20 \%$. The second factor that renders ERCOT a good fit for this study is that it does not have significant grid scale storage capacity $(0.25 \mathrm{GW})$. High levels of storage capacity would make the estimation of the causal effect more complicated as wind energy would inevitably be stored to be used (and displace fuels) in the later hours. Therefore, the full effect would be captured over the course of multiple hours requiring a more dynamic estimation approach. The third factor is that ERCOT is rather isolated from the other electrical grids, making it sufficient to confine the study to the plants in the grid to capture the full effect [10].

Economic theory shows that the efficient way of correcting for externalities is to charge a tax equal to marginal damages, i.e., Pigovian taxes [11,12]. However, in the US, the use of these policies have so far been rather limited. Current environmental policies catering to the energy sector are predominantly geared toward mandates and financial incentives for renewable energy sources. At the state level, renewable portfolio standards (RPS) require a minimum share of electricity to be generated from renewable resources [13]. Currently, 38 states have an RPS goal in place, with 12 of those states requiring $100 \%$ clean electricity by 2050 or earlier [14]. At the federal level, there is a production tax credit for renewable electricity [15]. Such a policy environment motivated researchers from both economics and engineering to estimate the emission reductions attributable to renewable energy sources with the overarching objective to evaluate whether government incentives are justified on the grounds of net economic benefit.

Although at a first glance, calculating emission reductions due to renewable energy sources might seem as straightforward as multiplying average emissions per $\mathrm{kWh}$ of fossilfuel generation by total renewable energy output, this would, in fact, not be the correct approach. A more careful way of thinking about this problem involves identifying which power plant(s) would pause or reduce operations when the renewable energy sources are dispatched. Emissions avoided due to these marginal power plants reducing their operations would amount to the environmental benefits of renewable sources. In principle, marginal power plants can be identified using a dispatch model based on the assumption 
that renewables would replace high-marginal-cost plants. The papers that take this general approach include [16-20]. The prevailing insight from this group of studies is that while an increased level of renewable integration would reduce emissions, the magnitude of the effect depends on the existing fuel mix and technical characteristics of the system. While this method is more accurate compared to using the average emissions, performing a full dynamic optimization analysis would require often hard-to-access grid dispatch models and proprietary data on transmission lines and individual generating units.

More recently, an alternative approach pioneered by [21] emerged in the economics literature. The core idea here is that instead of calculating the avoided emissions as a result of solving a grid optimization problem using a dispatch model, we could estimate it using publicly available emissions and generation data and econometric methods. There is a growing strand in the energy economics literature adopting this method (e.g., [10,22-24]).

There are two important areas in the current literature studying the avoided emissions attributable to wind that are open to further elaboration. The first one is that these studies are conducted using hourly data from relatively short periods of time. With the exception of [10] who studied a 5-year period, the time periods of the studies in the literature are limited to one to two years. Therefore, their results can only be informative within a limited range of installed capacity, implying a need for studies using data from longer periods.

Second, while many studies investigate the environmental benefits of renewable energy, the subset of these studies specifically taking intermittency into account are rather limited. Notable recent exceptions are $[7,24]$. Using two years of sub-hourly data from the Southern Power Pool, [24] estimates the effect of wind and its intermittency on emissions. They find that while the increased renewable capacity does reduce emissions, the effect of intermittency is modest in comparison. In their analysis using data aggregated to a $5 \mathrm{~h}$ level from a 2 year period, [7] presents estimates for $\mathrm{CO}_{2}$ within ERCOT. The study concludes that intermittency in wind reduces $\mathrm{CO}_{2}$ emissions by indirectly giving natural gas facilities an advantage due to their flexibility. Our study mainly builds on these papers while complementing them in three important ways.

First, our study uses a dataset that ranges from January 2007 to December 2019, which makes it the first paper that econometrically estimates the causal effect of wind and its intermittency using sub-hourly data that spans well over a decade. Throughout this period, we see a seven-fold increase in the installed wind capacity (see the last two columns of Table 1). Second, the fact that we use a much longer period of time allows us to present two sets of results for each pollutant: results obtained using the entire dataset (henceforth referred to as the "pooled results") and results from breaking down the data into 10 subgroups based on hourly wind generation. Therefore, unlike any of the existing studies in the literature, we provide the comparison of the relationship between the wind generation, its volatility, and the emissions for a variety of wind output levels. Third, the majority of the existing studies consider the effects of wind and its intermittency on emissions linearly in their main econometric specifications, and a small minority present the results of their non-linear analyses in their appendices. In this paper, we incorporate non-linearity in two distinct ways: (i) by breaking data into different wind output intervals (ii) by specifying wind and its intermittency in squared and cubed form in addition to linear form in the estimation models.

\section{Preview of Results}

Our main variables of interest are hourly wind generation and its volatility which we measured via the the standard deviation calculated using the 15 min electricity generation data from ERCOT. We find that for all three pollutants we studied $\left(\mathrm{CO}_{2}, \mathrm{NO}_{x}\right.$, and $\left.\mathrm{SO}_{2}\right)$ wind generation had a clear negative effect throughout the study period with moderate variation in the magnitude depending on the wind output. However, for the intermittency, size, magnitude, and statistical significance of the effect have a large variation across different wind generation levels as well as pollutants in an irregular way that would not be captured in the pooled results. This finding is consequential for accurately estimating 
the environmental benefits of renewable energy and designing effective and efficient environmental and energy policy.

The rest of the paper continues as follows: Section 2 presents data sources and the econometric strategy. Results and their discussions can be found in Section 3. Section 4 offers concluding remarks.

\section{Data and Econometric Strategy}

\subsection{Data}

Our study period ranges from 1 January 2007 to 31 December 2019, with more than 113 thousand hours of observations of generation, load, emissions, and temperature data from the ERCOT region. Table 1 lays out how the number and capacity of generators that use fossil fuel and wind change over time. This information was compiled from the EIA Forms 923 and 860.

Table 1. Number and capacity of generating units using fossil fuels and wind over years.

\begin{tabular}{lllllllll}
\hline Fuel Type & \multicolumn{2}{l}{ Coal } & \multicolumn{3}{c}{ Natural Gas } & \multicolumn{2}{c}{ Natural Gas (CC) } & \multicolumn{2}{c}{ Wind } \\
\hline Year & Units & Cap. (MW) & Units & Cap. (MW) & Units & Cap. (MW) & Units & Cap. (MW) \\
\hline 2007 & 30 & $16,608.9$ & 317 & $49,513.5$ & 179 & $14,015.7$ & 30 & 3710.5 \\
2008 & 30 & $16,608.9$ & 312 & $48,984.2$ & 179 & $14,522.3$ & 50 & 6646.2 \\
2009 & 30 & $16,648.3$ & 285 & $46,259.3$ & 153 & $13,742.0$ & 63 & 8605.8 \\
2010 & 32 & $19,132.0$ & 326 & $48,667.2$ & 152 & $13,227.4$ & 71 & 9326.9 \\
2011 & 32 & $19,826.6$ & 321 & $46,212.9$ & 157 & $13,917.1$ & 74 & 9636.1 \\
2012 & 36 & $20,289.1$ & 310 & $45,550.5$ & 154 & $13,645.3$ & 81 & $10,585.9$ \\
2013 & 34 & $20,821.9$ & 325 & $44,499.7$ & 152 & $13,611.0$ & 87 & $11,361.5$ \\
2014 & 33 & $20,817.2$ & 315 & $45,088.7$ & 161 & $14,032.7$ & 90 & $12,222.6$ \\
2015 & 35 & $20,874.4$ & 322 & $46,780.9$ & 158 & $14,037.0$ & 111 & $16,040.1$ \\
2016 & 36 & $20,879.1$ & 333 & $45,863.3$ & 160 & $14,047.3$ & 125 & $18,941.2$ \\
2017 & 36 & $20,879.1$ & 343 & $49,847.3$ & 146 & $13,090.9$ & 137 & $21,080.6$ \\
2018 & 29 & $16,460.2$ & 366 & $50,819.3$ & 146 & $12,923.2$ & 141 & $22,277.5$ \\
2019 & 26 & $15,074.7$ & 374 & $51,223.3$ & 142 & $12,698.3$ & 156 & $25,683.9$ \\
\hline
\end{tabular}

Figure 1 visualizes how the composition of the fuel sources as a share of total generation evolved over time, clearly indicating a fast increase in the share of wind within the overall generation mix.

Generation and emissions data comprise the core of our dataset. Publicly available $15 \mathrm{~min}$ wind generation data were downloaded from the ERCOT database. We aggregated these at the hourly level to match the other datasets to find the hourly total wind generation and its within-hour standard deviation. Hourly emissions data of carbon dioxide $\left(\mathrm{CO}_{2}\right)$, nitrogen oxides $\left(\mathrm{NO}_{x}\right)$, and sulphur dioxide $\left(\mathrm{SO}_{2}\right)$ were obtained from the Continuous Emission Monitoring Systems (CEMS) through the Environmental Protection Agency (EPA). We note that CEMS database does only includes generation units with a capacity greater than or equal to $25 \mathrm{MW}$; hence, this analysis is confined to emissions from those units. Finally, hourly temperature data were downloaded from the National Oceanic and Atmospheric Administration (NOAA). Summary statistics can be found in Table 2. 


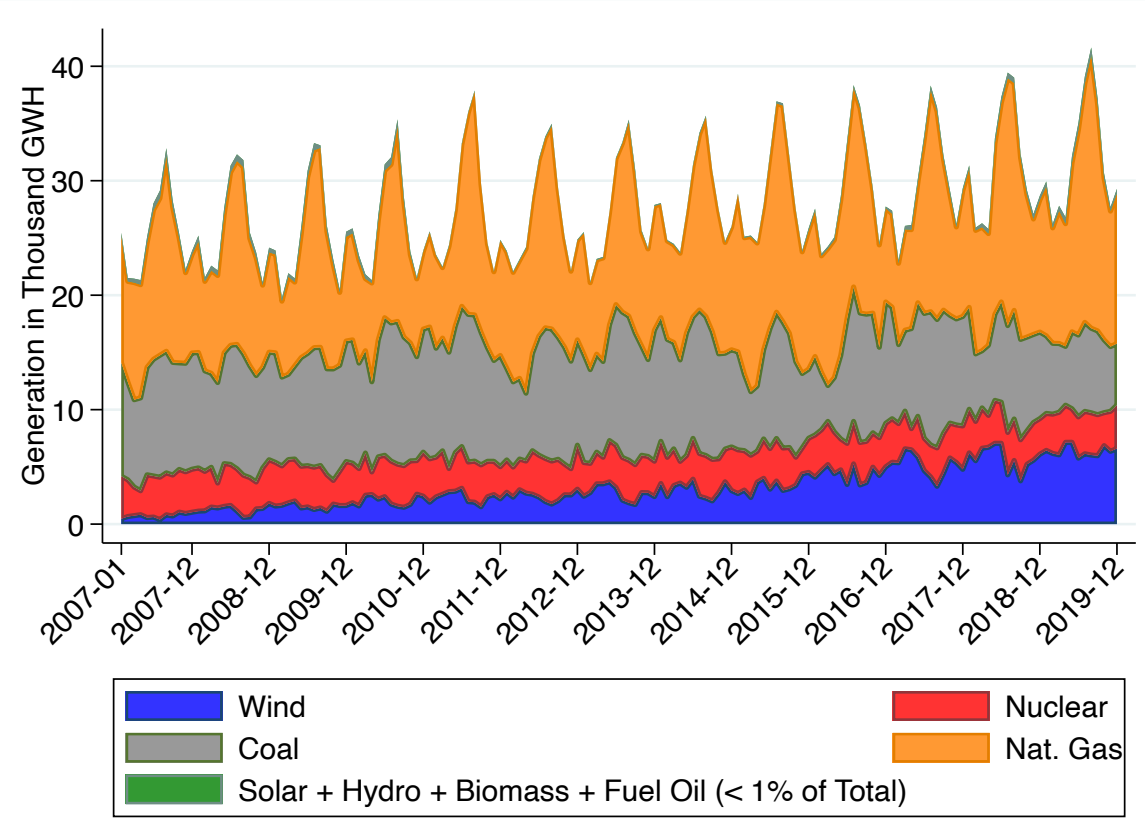

Figure 1. Electricity generation by fuel type over time in ERCOT.

Table 2. Summary Statistics.

\begin{tabular}{|c|c|c|}
\hline Variable & Mean & Std. Dev. \\
\hline Nat. Gas Gen. (MWh) & $16,484.98$ & 7739.84 \\
\hline Coal Gen. (MWh) & $12,601.34$ & 3190.61 \\
\hline Nuclear Gen. (MWh) & 4584.81 & 758.23 \\
\hline Wind Gen. (MWh) & 4361.99 & 3607.35 \\
\hline Hydro Gen. (MWh) & 82.65 & 79.82 \\
\hline Solar Gen. (MWh) & 103.07 & 288.85 \\
\hline Other Gen. (MWh) & 194.33 & 230.07 \\
\hline Wind SD & 36.41 & 35.15 \\
\hline Load (MW) & $38,528.93$ & 9464.12 \\
\hline Avg. Temp. Celcius & 19.25 & 8.89 \\
\hline $\mathrm{CO}_{2}$ Emissions (tons) & $28,869.07$ & 7185.75 \\
\hline $\mathrm{NO}_{x}$ Emissions (lbs) & $29,522.43$ & 9435.99 \\
\hline $\mathrm{SO}_{2}$ Emissions (lbs) & $79,203.40$ & $29,464.94$ \\
\hline Load (MW) & $38,528.93$ & 9464.12 \\
\hline $\mathrm{N}$ & \multicolumn{2}{|c|}{113,934} \\
\hline
\end{tabular}

\subsection{Econometric Strategy}

In the literature, we identified four main distinct mechanisms through which integrating renewable energy into the grid affects emissions. The primary mechanism is via displacing fossil-fuel sources. In the absence of large-scale storage facilities connected to the grid, generation (supply) needs to match load (demand) instantaneously in order to avoid severe damages to the system [25]. Therefore, holding the load constant, one-unit of increase in generation from a given renewable source needs to be counterbalanced by a one-unit decrease in output from the rest of the generating fleet, which are fossil-fuel burning sources.

The second mechanism works through ramping up and down some of the units in the remaining generation fleet as a response to fluctuations in the renewable sources in order to balance load and generation in the grid. This is a fuel-intensive process and can increase the per-unit emissions from fossil units. 
The third mechanism is associated with the elevated need for flexible generating units to accommodate the gradually growing magnitude of intermittency as more wind power is integrated into the system. If the system operator anticipates a higher level of volatility, this can cause them to preemptively dispatch flexible generators (natural gas) at a higher intensity, potentially leading to reduction in overall emissions, as explained in [7].

Finally, the fourth mechanism is due to differing heat rates of thermal power plants at different output levels. Being forced to operate at suboptimal levels can lead to higher than normal heat rates (fuel per unit of output) leading to higher emissions per unit of generation $([8,26])$.

We note that there is a fifth mechanism pertaining to mostly solar technologies. Some solar units are hybridized with fossil burning units (most frequently natural gas) as a backup to stabilize generation and avoid freezing. This introduces carbon emissions to solar generation, limiting its environmental benefits. We do not discuss this mechanism in this paper as solar comprises a very small portion of generation in ERCOT.

These mechanisms can formally be represented via the following static model modified from [24].

$$
E_{t}=\sum_{i} Q_{i t}\left(W_{t}, \sigma_{t}, L_{t}, T_{t}\right) \cdot \delta_{i}\left(W_{t}, \sigma_{t}\right)
$$

where $E_{t}$ denotes the total emissions in a given hour $t$, and $i$ is the index for fossil-fuel plants. During time period $t$ :

$W_{t}$ is the system-wide wind generation;

$\sigma_{t}$ is the volatility in wind generation;

$L_{t}$ is the system-wide load (demand);

$T_{t}$ is the temperature;

$Q_{i t}$ is the total generation from plant $i$. In addition to $L_{t}$ and $T_{t}, Q_{i t}$ is modeled to be a function of $W_{t}$ due to the first mechanism described above and $\sigma_{t}$ due to the third mechanism.

$\delta_{i}\left(W_{t}, \sigma_{t}\right)$ is the emission rate per unit of output. It is modeled to be a function of $\sigma_{t}$ and $W_{t}$ to account for the second and fourth mechanisms listed above, respectively.

Therefore, the emissions in a given hour can be succinctly represented as follows:

$$
E_{t}=\phi\left(L_{t}, W_{t}, T_{t}, \sigma_{t}\right)
$$

We approximate Equation (2) with the following reduced-form econometric model.

$$
E_{t}=\beta_{0}+\alpha\left(W_{t}\right)+\gamma\left(\sigma_{t}\right)+\lambda\left(L_{t}\right)+\tau\left(T_{t}\right)+\beta_{1} D o W_{t}+\beta_{2} M Y_{t}+\beta_{3} H M_{t}+\varepsilon_{t}
$$

where $\alpha\left(W_{t}\right), \gamma\left(\sigma_{t}\right), \lambda\left(L_{t}\right)$, and $\tau\left(T_{t}\right)$ are the polynomial functions of $W_{t}, \sigma_{t}, L_{t}$, and, $T_{t}$, respectively. This is the common functional form used elsewhere in the literature, except that wind and its intermittency are only included in their linear form. $\varepsilon_{t}$ is the stochastic error term; and $D_{o} W_{t}, M Y_{t}, H M_{t}$ are vectors of dummy variables for day of week, monthyear, and hour-month, respectively. The dummy variables are utilized in order to account for potential unobserved factors that affect both the outcome (emissions) and the variable of interest (intermittency) as well as other variables at the same time. Not including them could lead to wrongfully attributing the effect of the unobserved factors to variables included in the regressions (i.e., bias). In addition, including these variables reduces the noise (variance of the error term) leading to increased precision in the estimates. Hourmonth indicators capture season-specific within-day wind patterns that could also affect the load profile. The load profile is linked to emissions as it determines which power plants are on the margin. Month-year indicators can be considered as a monthly trend variable to account for time-varying factors that affect the composition of the generation fleet and hence emissions. Day-of-week indicators are included to account for different load profiles within week. Our identifying assumption is that the given load, temperature, and all the fixed effects listed above, generation from wind, and its intermittency are as 
good as random. Conditional on this assumption, the marginal effects calculated here are interpretable as causal effects.

\section{Results and Discussion}

We ran the regression laid out in Equation (3) for $\mathrm{CO}_{2}, \mathrm{NO}_{x}$, and $\mathrm{SO}_{2}$ emissions. The exercise started out with a pooled analysis where different econometric specifications with an increasing degree of polynomials for wind and its intermittency were used on the entire dataset. In addition, load and temperature were included in polynomial forms up to cubic. This flexible approach is suitable for the non-linear nature of the grid operations. Presenting results for alternative specifications with different polynomial degrees also allowed us to demonstrate the variation in the robustness of different coefficients. For each pollutant, we selected a specification from the pooled analysis and then continued with running that same specification over subsets of observations. We divided the dataset into 10 subsets based on hourly wind generation level. Within the sub-sample, the means and the standard deviations (in parentheses) of wind generation and its intermittency are presented in Table 3. The motivation for this exercise is to further increase the flexibility of the models by allowing for irregularities and/or discontinuities in the relationship pattern that a polynomial functional form could not capture despite being non-linear. As noted above, hour-month dummies implicitly control for the growing trend in installed capacity. The insight to be gained here is that controlling for capacity and other factors, whether the marginal effects of wind generation and its intermittency, vary across hours with different wind generation output levels.

Table 3. Means and standard deviations of wind generation and its intermittency across different intervals.

\begin{tabular}{|c|c|c|c|}
\hline & & $\begin{array}{c}\text { Wind } \\
\text { Generation }\end{array}$ & $\begin{array}{l}\text { Intermittency of } \\
\text { Wind Generation }\end{array}$ \\
\hline Interval & Mean & 318.83 & 9.48 \\
\hline 1 & Std. Dev. & (189.00) & (9.01) \\
\hline Interval & Mean & 968.37 & 19.79 \\
\hline 2 & Std. Dev. & (186.31) & (15.48) \\
\hline Interval & Mean & 1619.90 & 26.43 \\
\hline 3 & Std. Dev. & (189.86) & (23.05) \\
\hline Interval & Mean & 2294.01 & 31.13 \\
\hline 4 & Std. Dev. & (200.18) & (25.07) \\
\hline Interval & Mean & 3010.00 & 36.02 \\
\hline 5 & Std. Dev. & (215.88) & (29.17) \\
\hline Interval & Mean & 3815.06 & 40.46 \\
\hline 6 & Std. Dev. & (257.27) & (33.27) \\
\hline Interval & Mean & 4823.03 & 44.82 \\
\hline 7 & Std. Dev. & (331.42) & (36.36) \\
\hline Interval & Mean & 6125.58 & 46.93 \\
\hline 8 & Std. Dev. & (445.16) & (39.89) \\
\hline Interval & Mean & 8204.24 & 54.57 \\
\hline 9 & Std. Dev. & (779.64) & (45.38) \\
\hline Interval & Mean & $12,445.10$ & 54.51 \\
\hline 10 & Std. Dev. & (1942.85) & (44.31) \\
\hline
\end{tabular}


We first present the pooled analyses of each pollutant. The results in Table 4 indicate a significant effect of wind generation on $\mathrm{CO}_{2}$ emissions. The size, magnitude, and the significance of the coefficient is fairly robust and consistent across different specifications. The coefficient estimates for wind generation are between -0.53 and -0.65 , which is in line with previous estimates published in the literature (e.g., $[10,24])$. We note that all standard errors reported in this study are clustered at the week level.

Table 4. $\mathrm{CO}_{2}$-emissions response to wind generation and intermittency: pooled analysis.

\begin{tabular}{|c|c|c|c|c|c|c|c|c|c|}
\hline & (1) & (2) & (3) & (4) & (5) & (6) & (7) & (8) & (9) \\
\hline Wind Gen. (MWh) & $\begin{array}{c}-0.649^{* * *} \\
(0.005)\end{array}$ & $\begin{array}{c}-0.627^{* * *} \\
(0.011)\end{array}$ & $\begin{array}{c}-0.525^{* * *} \\
(0.020)\end{array}$ & $\begin{array}{c}-0.649^{* * *} \\
(0.005)\end{array}$ & $\begin{array}{c}-0.630 * * * \\
(0.011)\end{array}$ & $\begin{array}{c}-0.531^{* * *} \\
(0.020)\end{array}$ & $\begin{array}{c}-0.649 * * * \\
(0.005)\end{array}$ & $\begin{array}{c}-0.630 * * * \\
(0.011)\end{array}$ & $\begin{array}{c}-0.531^{* * *} \\
(0.020)\end{array}$ \\
\hline Wind Gen. Sq. & & $\begin{array}{c}-0.000 * \\
(0.000)\end{array}$ & $\begin{array}{c}-0.000 * * * \\
(0.000)\end{array}$ & & $\begin{array}{c}-0.000 \\
(0.000)\end{array}$ & $\begin{array}{c}-0.000^{* * *} \\
(0.000)\end{array}$ & & $\begin{array}{r}-0.000 \\
(0.000)\end{array}$ & $\begin{array}{c}-0.000^{* * *} \\
(0.000)\end{array}$ \\
\hline Wind Gen. Cb. & & & $\begin{array}{c}0.000 * * * \\
(0.000)\end{array}$ & & & $\begin{array}{c}0.000^{* * *} \\
(0.000)\end{array}$ & & & $\begin{array}{c}0.000 \text { *** } \\
(0.000)\end{array}$ \\
\hline Wind SD & $\begin{array}{l}-0.114 \\
(0.166)\end{array}$ & $\begin{array}{l}-0.275 \\
(0.171)\end{array}$ & $\begin{array}{c}-0.360 * \\
(0.171)\end{array}$ & $\begin{array}{c}1.206^{* * *} \\
(0.278)\end{array}$ & $\begin{array}{c}0.978^{* * *} \\
(0.266)\end{array}$ & $\begin{array}{c}0.628 * * \\
(0.241)\end{array}$ & $\begin{array}{c}1.623^{* * *} \\
(0.396)\end{array}$ & $\begin{array}{c}1.331^{* * *} \\
(0.385)\end{array}$ & $\begin{array}{c}0.631 \\
(0.382)\end{array}$ \\
\hline Wind SD Sq. & & & & $\begin{array}{c}-0.008^{* * *} \\
(0.001)\end{array}$ & $\begin{array}{c}-0.008^{* * *} \\
(0.001)\end{array}$ & $\begin{array}{c}-0.006^{* * *} \\
(0.001)\end{array}$ & $\begin{array}{c}-0.012^{* * *} \\
(0.003)\end{array}$ & $\begin{array}{c}-0.011^{* * *} \\
(0.003)\end{array}$ & $\begin{array}{c}-0.006 \text { * } \\
(0.003)\end{array}$ \\
\hline Wind SD Cb. & & & & & & & $\begin{array}{l}0.000 * \\
(0.000)\end{array}$ & $\begin{array}{c}0.000 \\
(0.000)\end{array}$ & $\begin{array}{c}0.000 \\
(0.000) \\
\end{array}$ \\
\hline Observations & 113,934 & 113,934 & 113,934 & 113,934 & 113,934 & 113,934 & 113,934 & 113,934 & 113,934 \\
\hline Adjusted $R^{2}$ & 0.980 & 0.980 & 0.980 & 0.980 & 0.980 & 0.980 & 0.980 & 0.980 & 0.980 \\
\hline Load & $\mathrm{Y}$ & $\mathrm{Y}$ & Y & $\mathrm{Y}$ & $\mathrm{Y}$ & $\mathrm{Y}$ & $\mathrm{Y}$ & Y & $\mathrm{Y}$ \\
\hline Load Sq. \& Cb. & $\mathrm{Y}$ & $\mathrm{Y}$ & $\mathrm{Y}$ & $\mathrm{Y}$ & Y & $\mathrm{Y}$ & Y & $\mathrm{Y}$ & $\mathrm{Y}$ \\
\hline Temp. & Y & $\mathrm{Y}$ & $\mathrm{Y}$ & $\mathrm{Y}$ & $\mathrm{Y}$ & $\mathrm{Y}$ & Y & Y & $\mathrm{Y}$ \\
\hline Temp. Sq. \& Cb. & $\mathrm{Y}$ & $\mathrm{Y}$ & $\mathrm{Y}$ & $\mathrm{Y}$ & Y & $\mathrm{Y}$ & Y & Y & $\mathrm{Y}$ \\
\hline DOW & Y & $\mathrm{Y}$ & Y & Y & Y & $\mathrm{Y}$ & Y & $\mathrm{Y}$ & Y \\
\hline Month-Year & Y & $\mathrm{Y}$ & Y & $\mathrm{Y}$ & Y & $\mathrm{Y}$ & Y & $\mathrm{Y}$ & Y \\
\hline Hour-Month & Y & $\mathrm{Y}$ & $Y$ & $Y$ & Y & $Y$ & Y & $\mathrm{Y}$ & Y \\
\hline
\end{tabular}

Standard errors in parentheses, ${ }^{*} p<0.05,{ }^{* *} p<0.01$, and ${ }^{* * *} p<0.001$.

The goodness-of-fit measures are very close across the models; therefore, for model selection, we take statistical significance and size of the coefficients as well as parsimony into consideration. The coefficients of the squared and cubed wind generation are statistically significant; however, they are negligible in size. The coefficient of cubed wind intermittency measure is also negligible statistically and in size. Therefore, for the sake of parsimony, our preferred specification for $\mathrm{CO}_{2}$ is model (4) where wind generation is in linear form and intermittency is in quadratic form. The coefficient of wind generation, 0.649 , gives its marginal effect since it is in linear form.

While it is not as robust as the coefficient of wind generation, that of intermittency has positive and significant coefficients in most of the models. The sign reverses with the inclusion of the squared intermittency-the coefficient of which is negative and significant. This is consistent with our original conjecture that higher degree polynomials can offer a more suitable functional form when estimating emission reductions. Intermittency is included in quadratic form in the preferred specification; therefore, the marginal effect is given by the following partial derivative:

$$
\frac{\partial \mathrm{CO}_{2}}{\partial \text { Wind Int. }}=\beta_{1}+2 \beta_{2} \text { Wind Int. }
$$

where the term "Wind Int." is substituted with its overall sample mean, which is 36.41 as indicated in Table 2. The marginal effect is calculated as 0.603 , while the $95 \%$ confidence 
interval (CI) constructed using the Delta method is [0.21, 0.99]. All marginal effects are summarized in the results section.

The results of the pooled analysis for $\mathrm{NO}_{x}$ are presented in Table 5. For this pollutant, we select specification (7). Squared and cubic wind generation terms are statistically significant, but their size is negligible. Similar to $\mathrm{CO}_{2}$, the results indicate an unequivocally negative effect of wind generation on $\mathrm{NO}_{x}$ emissions, and the size of the effect is fairly robust across different specifications. This result is also consistent with other studies while, as it would be expected, the size of the effect is different for different regions. The marginal effect of wind generation on $\mathrm{NO}_{x}$ indicated in our models ranges between -0.65 and -0.99 . This result is similar to that presented in [10] who also studies the ERCOT region.

For intermittency, while the cubic term is negligible in size, its inclusion makes a difference for the squared term (comparing models (4) and (7)). In the cubic form, the marginal effect is given by the following partial derivative:

$$
\frac{\partial N O_{x}}{\partial \text { Wind Int. }}=\theta_{1}+2 \theta_{2} \text { Wind Int. }+3 \theta_{3} \text { Wind Int. }^{2}
$$

It calculates to -3.918; hence, we conclude that intermittency has a reducing effect on $\mathrm{NO}_{x}$. This is qualitatively similar to the results presented in [24] for $\mathrm{NO}_{x}$. Again, the size of the effect differs as they study a different transmission region.

Table 5. $\mathrm{NO}_{x}$-emissions response to wind generation and intermittency: pooled analysis.

\begin{tabular}{|c|c|c|c|c|c|c|c|c|c|}
\hline & (1) & (2) & (3) & (4) & (5) & (6) & (7) & (8) & (9) \\
\hline Wind Gen. (MWh) & $\begin{array}{c}-0.647^{* * *} \\
(0.012)\end{array}$ & $\begin{array}{c}-0.861^{* * *} \\
(0.031)\end{array}$ & $\begin{array}{c}-0.9911^{* * *} \\
(0.052)\end{array}$ & $\begin{array}{c}-0.647^{* * *} \\
(0.012)\end{array}$ & $\begin{array}{c}-0.862 \text { *** } \\
(0.031)\end{array}$ & $\begin{array}{c}-0.995^{* * *} \\
(0.052)\end{array}$ & $\begin{array}{c}-0.646^{* * *} \\
(0.012)\end{array}$ & $\begin{array}{c}-0.861 \text { *** } \\
(0.031)\end{array}$ & $\begin{array}{c}-0.993^{* * *} \\
(0.052)\end{array}$ \\
\hline Wind Gen. Sq. & & $\begin{array}{c}0.000 * * * \\
(0.000)\end{array}$ & $\begin{array}{c}0.000 * * * \\
(0.000)\end{array}$ & & $\begin{array}{c}0.000^{* * *} \\
(0.000)\end{array}$ & $\begin{array}{c}0.000 * * * \\
(0.000)\end{array}$ & & $\begin{array}{c}0.000^{* * *} \\
(0.000)\end{array}$ & $\begin{array}{c}0.000^{* * * *} \\
(0.000)\end{array}$ \\
\hline Wind Gen. $\mathrm{Cb}$. & & & $\begin{array}{c}-0.000 \text { ** } \\
(0.000)\end{array}$ & & & $\begin{array}{c}-0.000 \text { ** } \\
(0.000)\end{array}$ & & & $\begin{array}{c}-0.000 \text { ** } \\
(0.000)\end{array}$ \\
\hline Wind SD & $\begin{array}{c}-2.973^{* * *} \\
(0.367)\end{array}$ & $\begin{array}{c}-1.393^{* * * *} \\
(0.362)\end{array}$ & $\begin{array}{c}-1.286^{* * *} \\
(0.364)\end{array}$ & $\begin{array}{c}-3.515^{* * *} \\
(0.830)\end{array}$ & $\begin{array}{l}-1.020 \\
(0.670)\end{array}$ & $\begin{array}{l}-0.549 \\
(0.606)\end{array}$ & $\begin{array}{c}-5.130^{* * *} \\
(0.963)\end{array}$ & $\begin{array}{c}-1.891 * \\
(0.918)\end{array}$ & $\begin{array}{l}-0.959 \\
(0.885)\end{array}$ \\
\hline Wind SD Sq. & & & & $\begin{array}{c}0.003 \\
(0.004)\end{array}$ & $\begin{array}{l}-0.002 \\
(0.003)\end{array}$ & $\begin{array}{l}-0.005 \\
(0.002)\end{array}$ & $\begin{array}{c}0.018^{* *} \\
(0.006)\end{array}$ & $\begin{array}{c}0.005 \\
(0.006)\end{array}$ & $\begin{array}{l}-0.001 \\
(0.006)\end{array}$ \\
\hline Wind SD Cb. & & & & & & & $\begin{array}{c}-0.000^{* * *} \\
(0.000)\end{array}$ & $\begin{array}{l}-0.000 \\
(0.000) \\
\end{array}$ & $\begin{array}{l}-0.000 \\
(0.000) \\
\end{array}$ \\
\hline Observations & 113,934 & 113,934 & 113,934 & 113,934 & 113,934 & 113,934 & 113,934 & 113,934 & 113,934 \\
\hline Adjusted $R^{2}$ & 0.936 & 0.937 & 0.937 & 0.936 & 0.937 & 0.937 & 0.936 & 0.937 & 0.937 \\
\hline Load & $\mathrm{Y}$ & $\mathrm{Y}$ & $\mathrm{Y}$ & $\mathrm{Y}$ & $\mathrm{Y}$ & $\mathrm{Y}$ & $\mathrm{Y}$ & $\mathrm{Y}$ & $\mathrm{Y}$ \\
\hline Load Sq. \& Cb. & $\mathrm{Y}$ & $\mathrm{Y}$ & $\mathrm{Y}$ & $\mathrm{Y}$ & $\mathrm{Y}$ & $\mathrm{Y}$ & $\mathrm{Y}$ & $\mathrm{Y}$ & $\mathrm{Y}$ \\
\hline Temp. & $\mathrm{Y}$ & $\mathrm{Y}$ & $\mathrm{Y}$ & $\mathrm{Y}$ & $\mathrm{Y}$ & $\mathrm{Y}$ & $\mathrm{Y}$ & $\mathrm{Y}$ & $\mathrm{Y}$ \\
\hline Temp. Sq. \& Cb. & $\mathrm{Y}$ & $\mathrm{Y}$ & $\mathrm{Y}$ & $\mathrm{Y}$ & $\mathrm{Y}$ & $\mathrm{Y}$ & $\mathrm{Y}$ & $\mathrm{Y}$ & $\mathrm{Y}$ \\
\hline DOW & $\mathrm{Y}$ & $\mathrm{Y}$ & $\mathrm{Y}$ & $\mathrm{Y}$ & $\mathrm{Y}$ & $\mathrm{Y}$ & $\mathrm{Y}$ & $\mathrm{Y}$ & $\mathrm{Y}$ \\
\hline Month-Year & $\mathrm{Y}$ & $\mathrm{Y}$ & $\mathrm{Y}$ & $\mathrm{Y}$ & $\mathrm{Y}$ & $\mathrm{Y}$ & $\mathrm{Y}$ & $\mathrm{Y}$ & $\mathrm{Y}$ \\
\hline Hour-Month & $\mathrm{Y}$ & $\mathrm{Y}$ & $\mathrm{Y}$ & $\mathrm{Y}$ & $\mathrm{Y}$ & $\mathrm{Y}$ & $\mathrm{Y}$ & $\mathrm{Y}$ & $\mathrm{Y}$ \\
\hline
\end{tabular}

Standard errors in parentheses, ${ }^{*} p<0.05,{ }^{* *} p<0.01$, and ${ }^{* * *} p<0.001$.

The final pooled analysis we present is that of $\mathrm{SO}_{2}$, another local pollutant like $\mathrm{NO}_{x}$. The results can be found in Table 6. Similar to $\mathrm{CO}_{2}$ and the coefficient of wind generation is negative, significant, and robust across different specifications with marginal effect varying between -1.03 and 1.7, which again is very consistent with the current literature [10]. Again, squared and cubed coefficients are negligible in size. For the same reasons as $\mathrm{CO}_{2}$, the preferred model is (4). For intermittency, for most of the models the effect is positive and significant. The marginal effect of intermittency from model (4) is calculated as 3.07. 
Table 6. $\mathrm{SO}_{2}$-emissions response to wind generation and intermittency: pooled analysis.

\begin{tabular}{|c|c|c|c|c|c|c|c|c|c|}
\hline & (1) & $(2)$ & (3) & (4) & (5) & (6) & $(7)$ & (8) & (9) \\
\hline Wind Gen. (MWh) & $\begin{array}{c}-1.326^{* * *} \\
(0.039)\end{array}$ & $\begin{array}{c}-1.654^{* * *} \\
(0.088)\end{array}$ & $\begin{array}{c}-1.006^{* * *} \\
(0.169)\end{array}$ & $\begin{array}{c}-1.328^{* * *} \\
(0.039)\end{array}$ & $\begin{array}{c}-1.667^{* * *} \\
(0.088)\end{array}$ & $\begin{array}{c}-1.031^{* * *} \\
(0.170)\end{array}$ & $\begin{array}{c}-1.329^{* * *} \\
(0.039)\end{array}$ & $\begin{array}{c}-1.669 * * * \\
(0.088)\end{array}$ & $\begin{array}{c}-1.029^{* * *} \\
(0.170)\end{array}$ \\
\hline Wind Gen. Sq. & & $\begin{array}{c}0.000 * * * \\
(0.000)\end{array}$ & $\begin{array}{c}-0.000^{* * *} \\
(0.000)\end{array}$ & & $\begin{array}{c}0.000 * * * \\
(0.000)\end{array}$ & $\begin{array}{c}-0.000 * * * \\
(0.000)\end{array}$ & & $\begin{array}{c}0.000 * * * \\
(0.000)\end{array}$ & $\begin{array}{c}-0.000 * * * \\
(0.000)\end{array}$ \\
\hline Wind Gen. Cb. & & & $\begin{array}{c}0.000^{* * *} \\
(0.000)\end{array}$ & & & $\begin{array}{c}0.000 \text { *** } \\
(0.000)\end{array}$ & & & $\begin{array}{c}0.000^{* * *} \\
(0.000)\end{array}$ \\
\hline Wind SD & $\begin{array}{c}0.519 \\
(1.228)\end{array}$ & $\begin{array}{l}2.928 * \\
(1.183)\end{array}$ & $\begin{array}{l}2.390 * \\
(1.187)\end{array}$ & $\begin{array}{c}5.205^{* *} \\
(1.956)\end{array}$ & $\begin{array}{c}9.123^{* * *} \\
(1.924)\end{array}$ & $\begin{array}{c}6.873^{* * *} \\
(1.813)\end{array}$ & $\begin{array}{l}5.847 * \\
(2.952)\end{array}$ & $\begin{array}{c}10.982 \text { *** } \\
(2.734)\end{array}$ & $\begin{array}{l}6.482 * \\
(2.751)\end{array}$ \\
\hline Wind SD Sq. & & & & $\begin{array}{c}-0.029 * * * \\
(0.007)\end{array}$ & $\begin{array}{c}-0.038^{* * *} \\
(0.008)\end{array}$ & $\begin{array}{c}-0.028^{* * *} \\
(0.006)\end{array}$ & $\begin{array}{c}-0.035 \\
(0.018)\end{array}$ & $\begin{array}{c}-0.055^{* *} \\
(0.017)\end{array}$ & $\begin{array}{l}-0.024 \\
(0.017)\end{array}$ \\
\hline Wind SD Cb. & & & & & & & $\begin{array}{c}0.000 \\
(0.000)\end{array}$ & $\begin{array}{c}0.000 \\
(0.000)\end{array}$ & $\begin{array}{c}-0.000 \\
(0.000)\end{array}$ \\
\hline Observations & 113,934 & 113,934 & 113,934 & 113,934 & 113,934 & 113,934 & 113,934 & 113,934 & 113,934 \\
\hline Adjusted $R^{2}$ & 0.930 & 0.930 & 0.930 & 0.930 & 0.930 & 0.930 & 0.930 & 0.930 & 0.930 \\
\hline Load & Y & Y & Y & Y & $\mathrm{Y}$ & Y & Y & Y & Y \\
\hline Load Sq. \& Cb. & Y & Y & Y & Y & Y & Y & Y & $\mathrm{Y}$ & Y \\
\hline Temp. & Y & Y & Y & Y & Y & Y & Y & $\mathrm{Y}$ & Y \\
\hline Temp. Sq. \& Cb. & Y & $\mathrm{Y}$ & $\mathrm{Y}$ & Y & Y & Y & Y & Y & $\mathrm{Y}$ \\
\hline DOW & Y & Y & $\mathrm{Y}$ & Y & Y & Y & Y & Y & $\mathrm{Y}$ \\
\hline Month-Year & Y & Y & Y & Y & Y & Y & Y & Y & Y \\
\hline Hour-Month & Y & $Y$ & $Y$ & $Y$ & $Y$ & $Y$ & Y & $\mathrm{Y}$ & $\mathrm{Y}$ \\
\hline
\end{tabular}

Standard errors in parentheses, ${ }^{*} p<0.05,{ }^{* *} p<0.01$, and ${ }^{* *} p<0.001$.

Tables 7-9 extend the analysis into sub-samples for $\mathrm{CO}_{2}, \mathrm{NO}_{x}$, and $\mathrm{SO}_{2}$, respectively. We see a general pattern that is common to all three pollutants here: wind generation has a negative significant effect on all pollutants at all generation levels. While this effect is very stable for $\mathrm{CO}_{2}$, we see more of a variation for $\mathrm{NO}_{x}$ and $\mathrm{SO}_{2}$ at different generation levels. As far as wind intermittency goes, the results significantly differ at various levels of wind generation, and they all together differ from the pooled analysis for each of the pollutants. This implies that the wind generation level matters in net benefit calculations and the degree to which the results can be extrapolated is rather limited when we take intermittency into consideration.

Table 7. $\mathrm{CO}_{2}$-emissions response to wind generation and intermittency: analysis at different wind generation levels.

\begin{tabular}{lcccccccccc}
\hline & $\mathbf{( 1 )}$ & $\mathbf{( 2 )}$ & $\mathbf{( 3 )}$ & $\mathbf{( 4 )}$ & $\mathbf{( 5 )}$ & $\mathbf{( 6 )}$ & $\mathbf{( 7 )}$ & $\mathbf{( 8 )}$ & $\mathbf{( 9 )}$ & $\mathbf{( 1 0 )}$ \\
\hline Wind Gen. (MWh) & $-0.667^{* * *}$ & $-0.544^{* * *}$ & $-0.611^{* * *}$ & $-0.563^{* * *}$ & $-0.622^{* * *}$ & $-0.665^{* * *}$ & $-0.632^{* * *}$ & $-0.611^{* * *}$ & $-0.645^{* * *}$ & $-0.639^{* * *}$ \\
& $(0.110)$ & $(0.062)$ & $(0.054)$ & $(0.051)$ & $(0.051)$ & $(0.047)$ & $(0.036)$ & $(0.032)$ & $(0.021)$ & $(0.014)$ \\
Wind SD & 1.975 & 0.619 & 0.837 & 0.597 & 0.523 & 0.339 & 0.193 & $1.944^{* *}$ & 1.373 & 1.271 \\
& $(2.591)$ & $(1.783)$ & $(0.610)$ & $(1.050)$ & $(1.046)$ & $(0.963)$ & $(0.874)$ & $(0.733)$ & $(0.808)$ & $(0.654)$ \\
Wind SD Sq. & 0.012 & -0.018 & $-0.007^{* * *}$ & -0.012 & -0.009 & -0.004 & -0.001 & $-0.011^{* *}$ & $-0.009^{*}$ & $-0.011^{* * *}$ \\
& $(0.051)$ & $(0.025)$ & $(0.001)$ & $(0.009)$ & $(0.008)$ & $(0.006)$ & $(0.006)$ & $(0.004)$ & $(0.004)$ & $(0.003)$ \\
\hline Observations & 11,394 & 11,394 & 11,394 & 11,394 & 11,394 & 11,394 & 11,394 & 11,394 & 11,394 & 11,388 \\
Adjusted $R^{2}$ & 0.979 & 0.981 & 0.981 & 0.981 & 0.979 & 0.980 & 0.978 & 0.976 & 0.977 & 0.971 \\
Load & $\mathrm{Y}$ & $\mathrm{Y}$ & $\mathrm{Y}$ & $\mathrm{Y}$ & $\mathrm{Y}$ & $\mathrm{Y}$ & $\mathrm{Y}$ & $\mathrm{Y}$ & $\mathrm{Y}$ & $\mathrm{Y}$ \\
Load Sq. \& Cb. & $\mathrm{Y}$ & $\mathrm{Y}$ & $\mathrm{Y}$ & $\mathrm{Y}$ & $\mathrm{Y}$ & $\mathrm{Y}$ & $\mathrm{Y}$ & $\mathrm{Y}$ & $\mathrm{Y}$ & $\mathrm{Y}$ \\
Temp. & $\mathrm{Y}$ & $\mathrm{Y}$ & $\mathrm{Y}$ & $\mathrm{Y}$ & $\mathrm{Y}$ & $\mathrm{Y}$ & $\mathrm{Y}$ & $\mathrm{Y}$ & $\mathrm{Y}$ & $\mathrm{Y}$ \\
Temp. Sq. \& Cb. & $\mathrm{Y}$ & $\mathrm{Y}$ & $\mathrm{Y}$ & $\mathrm{Y}$ & $\mathrm{Y}$ & $\mathrm{Y}$ & $\mathrm{Y}$ & $\mathrm{Y}$ & $\mathrm{Y}$ & $\mathrm{Y}$ \\
DOW & $\mathrm{Y}$ & $\mathrm{Y}$ & $\mathrm{Y}$ & $\mathrm{Y}$ & $\mathrm{Y}$ & $\mathrm{Y}$ & $\mathrm{Y}$ & $\mathrm{Y}$ & $\mathrm{Y}$ & $\mathrm{Y}$ \\
Month-Year & $\mathrm{Y}$ & $\mathrm{Y}$ & $\mathrm{Y}$ & $\mathrm{Y}$ & $\mathrm{Y}$ & $\mathrm{Y}$ & $\mathrm{Y}$ & $\mathrm{Y}$ & $\mathrm{Y}$ & $\mathrm{Y}$ \\
Hour-Month & $\mathrm{Y}$ & $\mathrm{Y}$ & $\mathrm{Y}$ & $\mathrm{Y}$ & $\mathrm{Y}$ & $\mathrm{Y}$ & $\mathrm{Y}$ & $\mathrm{Y}$ & $\mathrm{Y}$ & $\mathrm{Y}$ \\
\hline
\end{tabular}


Table 8. $\mathrm{NO}_{x}$-emissions response to wind generation and intermittency: analysis at different wind generation levels.

\begin{tabular}{|c|c|c|c|c|c|c|c|c|c|c|}
\hline & (1) & (2) & (3) & (4) & (5) & (6) & (7) & (8) & (9) & (10) \\
\hline Wind Gen. (MWh) & $\begin{array}{c}-1.456^{* * *} \\
(0.280)\end{array}$ & $\begin{array}{c}-0.532 \text { ** } \\
(0.177)\end{array}$ & $\begin{array}{c}-0.571^{* * *} \\
(0.138)\end{array}$ & $\begin{array}{c}-0.819^{* * *} \\
(0.122)\end{array}$ & $\begin{array}{c}-0.998^{* * *} \\
(0.115)\end{array}$ & $\begin{array}{c}-0.897^{* * *} \\
(0.091)\end{array}$ & $\begin{array}{c}-0.649^{* * *} \\
(0.073)\end{array}$ & $\begin{array}{c}-0.602^{* * *} \\
(0.102)\end{array}$ & $\begin{array}{c}-0.587^{* * *} \\
(0.038)\end{array}$ & $\begin{array}{c}-0.524^{* * *} \\
(0.027)\end{array}$ \\
\hline Wind SD & $\begin{array}{l}-18.075 \\
(12.536)\end{array}$ & $\begin{array}{c}-10.248 \\
(7.277)\end{array}$ & $\begin{array}{l}-4.948 \\
(3.075)\end{array}$ & $\begin{array}{c}7.508 \\
(4.713)\end{array}$ & $\begin{array}{l}-0.839 \\
(3.954)\end{array}$ & $\begin{array}{l}-5.252 \\
(3.111)\end{array}$ & $\begin{array}{c}0.437 \\
(3.009)\end{array}$ & $\begin{array}{c}2.808 \\
(2.962)\end{array}$ & $\begin{array}{l}4.716^{*} \\
(1.952)\end{array}$ & $\begin{array}{c}1.568 \\
(1.520)\end{array}$ \\
\hline Wind SD Sq. & $\begin{array}{c}0.743 \\
(0.556)\end{array}$ & $\begin{array}{c}0.117 \\
(0.185)\end{array}$ & $\begin{array}{c}0.019 \\
(0.031)\end{array}$ & $\begin{array}{l}-0.154 \\
(0.080)\end{array}$ & $\begin{array}{c}0.004 \\
(0.058)\end{array}$ & $\begin{array}{c}0.062 \\
(0.036)\end{array}$ & $\begin{array}{l}-0.005 \\
(0.038)\end{array}$ & $\begin{array}{l}-0.042 \\
(0.030)\end{array}$ & $\begin{array}{c}-0.041 * \\
(0.019)\end{array}$ & $\begin{array}{l}-0.025 \\
(0.014)\end{array}$ \\
\hline Wind SD Cb. & $\begin{array}{l}-0.007 \\
(0.007)\end{array}$ & $\begin{array}{c}0.000 \\
(0.001)\end{array}$ & $\begin{array}{l}-0.000 \\
(0.000)\end{array}$ & $\begin{array}{c}0.001 \\
(0.000)\end{array}$ & $\begin{array}{l}-0.000 \\
(0.000)\end{array}$ & $\begin{array}{l}-0.000 \\
(0.000)\end{array}$ & $\begin{array}{c}0.000 \\
(0.000)\end{array}$ & $\begin{array}{c}0.000 \\
(0.000)\end{array}$ & $\begin{array}{c}0.000 \\
(0.000)\end{array}$ & $\begin{array}{c}0.000 \\
(0.000)\end{array}$ \\
\hline Observations & 11,394 & 11,394 & 11,394 & 11,394 & 11,394 & 11,394 & 11,394 & 11,394 & 11,394 & 11,388 \\
\hline Adjusted $R^{2}$ & 0.926 & 0.925 & 0.929 & 0.925 & 0.923 & 0.922 & 0.919 & 0.901 & 0.916 & 0.917 \\
\hline Load & $\mathrm{Y}$ & $\mathrm{Y}$ & Y & $\mathrm{Y}$ & $\mathrm{Y}$ & Y & $\mathrm{Y}$ & $\mathrm{Y}$ & $\mathrm{Y}$ & $\mathrm{Y}$ \\
\hline Load Sq. \& Cb. & Y & Y & Y & Y & Y & $\mathrm{Y}$ & Y & Y & Y & Y \\
\hline Temp. & Y & Y & Y & Y & Y & Y & Y & Y & Y & Y \\
\hline Temp. Sq. \& Cb. & $\mathrm{Y}$ & $\mathrm{Y}$ & $\mathrm{Y}$ & Y & $\mathrm{Y}$ & $\mathrm{Y}$ & $\mathrm{Y}$ & $\mathrm{Y}$ & Y & $\mathrm{Y}$ \\
\hline DOW & $\mathrm{Y}$ & Y & $\mathrm{Y}$ & $\mathrm{Y}$ & $\mathrm{Y}$ & $\mathrm{Y}$ & $\mathrm{Y}$ & Y & Y & $\mathrm{Y}$ \\
\hline Month-Year & $\mathrm{Y}$ & $\mathrm{Y}$ & $\mathrm{Y}$ & $\mathrm{Y}$ & $\mathrm{Y}$ & $\mathrm{Y}$ & $\mathrm{Y}$ & Y & Y & $\mathrm{Y}$ \\
\hline Hour-Month & Y & $\mathrm{Y}$ & Y & Y & Y & Y & $\mathrm{Y}$ & Y & Y & Y \\
\hline
\end{tabular}

Standard errors in parentheses, ${ }^{*} p<0.05,{ }^{* *} p<0.01$, and ${ }^{* *} p<0.001$.

Table 9. $\mathrm{SO}_{2}$-emissions response to wind generation and intermittency: analysis at different wind generation levels.

\begin{tabular}{lcccccccccc}
\hline & $\mathbf{( 1 )}$ & $\mathbf{( 2 )}$ & $\mathbf{( 3 )}$ & $\mathbf{( 4 )}$ & $\mathbf{( 5 )}$ & $\mathbf{( 6 )}$ & $\mathbf{( 7 )}$ & $\mathbf{( 8 )}$ & $\mathbf{( 9 )}$ & $\mathbf{( 1 0 )}$ \\
\hline Wind Gen. (MWh) & -0.207 & -0.438 & $-1.723^{* * *}$ & $-1.421^{* *}$ & $-1.616^{* * *}$ & $-1.877^{* * *}$ & $-1.547^{* * *}$ & $-1.170^{* * *}$ & $-1.345^{* * *}$ & $-0.850^{* * *}$ \\
& $(1.047)$ & $(0.563)$ & $(0.471)$ & $(0.481)$ & $(0.432)$ & $(0.366)$ & $(0.279)$ & $(0.234)$ & $(0.142)$ & $(0.078)$ \\
Wind SD & $55.193^{*}$ & -13.680 & 5.976 & 0.648 & 4.278 & 1.420 & 5.650 & -1.835 & $11.409^{*}$ & 4.603 \\
& $(23.495)$ & $(12.922)$ & $(5.221)$ & $(8.218)$ & $(7.823)$ & $(6.366)$ & $(5.988)$ & $(4.883)$ & $(4.549)$ & $(3.645)$ \\
Wind SD Sq. & $-1.265^{*}$ & 0.101 & $-0.038^{* * *}$ & -0.004 & -0.015 & -0.001 & -0.009 & 0.011 & $-0.067^{* *}$ & $-0.037^{*}$ \\
& $(0.502)$ & $(0.171)$ & $(0.007)$ & $(0.066)$ & $(0.054)$ & $(0.038)$ & $(0.033)$ & $(0.024)$ & $(0.022)$ & $(0.018)$ \\
\hline Observations & 11,394 & 11,394 & 11,394 & 11,394 & 11,394 & 11,394 & 11,394 & 11,394 & 11,394 & 11,388 \\
Adjusted $R^{2}$ & 0.853 & 0.889 & 0.890 & 0.897 & 0.893 & 0.896 & 0.900 & 0.898 & 0.882 & 0.864 \\
Load & $\mathrm{Y}$ & $\mathrm{Y}$ & $\mathrm{Y}$ & $\mathrm{Y}$ & $\mathrm{Y}$ & $\mathrm{Y}$ & $\mathrm{Y}$ & $\mathrm{Y}$ & $\mathrm{Y}$ & $\mathrm{Y}$ \\
Load Sq. \& Cb. & $\mathrm{Y}$ & $\mathrm{Y}$ & $\mathrm{Y}$ & $\mathrm{Y}$ & $\mathrm{Y}$ & $\mathrm{Y}$ & $\mathrm{Y}$ & $\mathrm{Y}$ & $\mathrm{Y}$ & $\mathrm{Y}$ \\
Temp. & $\mathrm{Y}$ & $\mathrm{Y}$ & $\mathrm{Y}$ & $\mathrm{Y}$ & $\mathrm{Y}$ & $\mathrm{Y}$ & $\mathrm{Y}$ & $\mathrm{Y}$ & $\mathrm{Y}$ & $\mathrm{Y}$ \\
Temp. Sq. \& Cb. & $\mathrm{Y}$ & $\mathrm{Y}$ & $\mathrm{Y}$ & $\mathrm{Y}$ & $\mathrm{Y}$ & $\mathrm{Y}$ & $\mathrm{Y}$ & $\mathrm{Y}$ & $\mathrm{Y}$ & $\mathrm{Y}$ \\
DOW & $\mathrm{Y}$ & $\mathrm{Y}$ & $\mathrm{Y}$ & $\mathrm{Y}$ & $\mathrm{Y}$ & $\mathrm{Y}$ & $\mathrm{Y}$ & $\mathrm{Y}$ & $\mathrm{Y}$ & $\mathrm{Y}$ \\
Month-Year & $\mathrm{Y}$ & $\mathrm{Y}$ & $\mathrm{Y}$ & $\mathrm{Y}$ & $\mathrm{Y}$ & $\mathrm{Y}$ & $\mathrm{Y}$ & $\mathrm{Y}$ & $\mathrm{Y}$ & $\mathrm{Y}$ \\
Hour-Month & $\mathrm{Y}$ & $\mathrm{Y}$ & $\mathrm{Y}$ & $\mathrm{Y}$ & $\mathrm{Y}$ & $\mathrm{Y}$ & $\mathrm{Y}$ & $\mathrm{Y}$ & $\mathrm{Y}$ & $\mathrm{Y}$ \\
\hline
\end{tabular}

Standard errors in parentheses, ${ }^{*} p<0.05,{ }^{* *} p<0.01$, and ${ }^{* * *} p<0.001$.

Marginal effects of wind and its intermittency on all pollutants both for pooled and group level results together with their respective standard errors are presented in Table 10. This table presents a summary of all the findings. The overarching results from these exercises are that (i) wind generation has unequivocal negative effect on all pollution and the effect is relatively stable; (ii) intermittency is an important factor that needs to be taken into consideration as it can matter for certain pollutants for certain generation intervals; and (iii) extrapolating results derived using data within limited ranges of wind output can be misleading when conducting cost-benefit calculations. 
Table 10. Marginal effects of wind generation and its intermittency.

\begin{tabular}{|c|c|c|c|c|c|c|}
\hline & $\frac{\partial \mathrm{CO}_{2}}{\partial \text { Wind Gen }}$ & $\frac{\partial C O_{2}}{\partial S d \text { Wind }}$ & $\frac{\partial N O_{x}}{\partial \text { Wind Gen }}$ & $\frac{\partial N O_{x}}{\partial S d \text { Wind }}$ & $\frac{\partial \mathrm{SO}_{2}}{\partial \text { Wind Gen }}$ & $\frac{\partial S_{2}}{\partial S d \text { Wind }}$ \\
\hline Pooled Results & $\begin{array}{c}-0.649 \text { *** } \\
(0.005)\end{array}$ & $\begin{array}{c}0.603^{* * *} \\
(0.202)\end{array}$ & $\begin{array}{c}-0.646^{* * *} \\
(0.012)\end{array}$ & $\begin{array}{c}-3.918^{* * *} \\
(0.597)\end{array}$ & $\begin{array}{c}-1.328^{* * *} \\
(0.039)\end{array}$ & $\begin{array}{c}3.065^{* *} \\
(1.556)\end{array}$ \\
\hline Range 1 Results & $\begin{array}{c}-0.667^{* * *} \\
(0.110)\end{array}$ & $\begin{array}{c}2.205 \\
(1.850)\end{array}$ & $\begin{array}{c}-1.456^{* * *} \\
(0.280)\end{array}$ & $\begin{array}{l}-5.914 \\
(5.413)\end{array}$ & $\begin{array}{l}-0.207 \\
(1.047)\end{array}$ & $\begin{array}{l}31.202 * \\
(16.481)\end{array}$ \\
\hline Range 2 Results & $\begin{array}{c}-0.544^{* * *} \\
(0.062)\end{array}$ & $\begin{array}{l}-0.081 \\
(0.964)\end{array}$ & $\begin{array}{c}-0.532 * * * \\
(0.177)\end{array}$ & $\begin{array}{c}-5.568^{* * *} \\
(2.331)\end{array}$ & $\begin{array}{l}-0.438 \\
(0.563)\end{array}$ & $\begin{array}{l}-9.685 \\
(7.675)\end{array}$ \\
\hline Range 3 Results & $\begin{array}{c}-0.611^{* * *} \\
(0.054)\end{array}$ & $\begin{array}{c}0.447 \\
(0.575)\end{array}$ & $\begin{array}{c}-0.571 * * * \\
(0.138)\end{array}$ & $\begin{array}{c}-3.976^{* *} \\
(1.763)\end{array}$ & $\begin{array}{c}-1.723^{* * *} \\
(0.471)\end{array}$ & $\begin{array}{c}3.957 \\
(4.940)\end{array}$ \\
\hline Range 4 Results & $\begin{array}{c}-0.563 \text { *** } \\
(0.051)\end{array}$ & $\begin{array}{l}-0.158 \\
(0.600)\end{array}$ & $\begin{array}{c}-0.819^{* * *} \\
(0.122)\end{array}$ & $\begin{array}{l}-0.131 \\
(1.519)\end{array}$ & $\begin{array}{c}-1.421 \text { *** } \\
(0.481)\end{array}$ & $\begin{array}{c}0.422 \\
(4.913)\end{array}$ \\
\hline Range 5 Results & $\begin{array}{c}-0.622 * * * \\
(0.051)\end{array}$ & $\begin{array}{l}-0.093 \\
(0.577)\end{array}$ & $\begin{array}{c}-0.998 * * * \\
(0.115)\end{array}$ & $\begin{array}{l}-0.812 \\
(1.277)\end{array}$ & $\begin{array}{c}-1.616^{* * *} \\
(0.432)\end{array}$ & $\begin{array}{c}3.207 \\
(4.534)\end{array}$ \\
\hline Range 6 Results & $\begin{array}{c}-0.665^{* * *} \\
(0.047)\end{array}$ & $\begin{array}{l}-0.012 \\
(0.534)\end{array}$ & $\begin{array}{c}-0.897 * * * \\
(0.091)\end{array}$ & $\begin{array}{l}-1.207 \\
(1.148)\end{array}$ & $\begin{array}{c}-1.877^{* * *} \\
(0.366)\end{array}$ & $\begin{array}{c}1.324 \\
(3.916)\end{array}$ \\
\hline Range 7 Results & $\begin{array}{c}-0.632 * * * \\
(0.036)\end{array}$ & $\begin{array}{c}0.123 \\
(0.466)\end{array}$ & $\begin{array}{c}-0.649^{* * *} \\
(0.073)\end{array}$ & $\begin{array}{c}0.237 \\
(0.918)\end{array}$ & $\begin{array}{c}-1.547^{* * *} \\
(0.279)\end{array}$ & $\begin{array}{c}4.864 \\
(3.526)\end{array}$ \\
\hline Range 8 Results & $\begin{array}{c}-0.611^{* * *} \\
(0.032)\end{array}$ & $\begin{array}{l}0.885 * * \\
(0.421)\end{array}$ & $\begin{array}{c}-0.602 \text { *** } \\
(0.102)\end{array}$ & $\begin{array}{l}-0.340 \\
(1.050)\end{array}$ & $\begin{array}{c}-1.170 * * * \\
(0.234)\end{array}$ & $\begin{array}{l}-0.777 \\
(3.030)\end{array}$ \\
\hline Range 9 Results & $\begin{array}{c}-0.645^{* * *} \\
(0.021)\end{array}$ & $\begin{array}{c}0.366 \\
(0.427)\end{array}$ & $\begin{array}{c}-0.587^{* * *} \\
(0.038)\end{array}$ & $\begin{array}{c}0.954 \\
(0.649)\end{array}$ & $\begin{array}{c}-1.345^{* * *} \\
(0.142)\end{array}$ & $\begin{array}{c}4.084 \\
(2.605)\end{array}$ \\
\hline Range 10 Results & $\begin{array}{c}-0.639 * * * \\
(0.014)\end{array}$ & $\begin{array}{c}0.092 \\
(0.416)\end{array}$ & $\begin{array}{c}-0.524^{* * *} \\
(0.027)\end{array}$ & $\begin{array}{l}-0.838 \\
(0.599)\end{array}$ & $\begin{array}{c}-0.850 * * * \\
(0.078)\end{array}$ & $\begin{array}{c}0.574 \\
(2.327)\end{array}$ \\
\hline
\end{tabular}

Standard errors in parentheses, ${ }^{*} p<0.05{ }^{* *} p<0.01$, and ${ }^{* * *} p<0.001$.

\section{Conclusions}

The electricity systems in the United States has seen a dramatic change toward clean but intermittent energy technologies over the recent years. While economic theory points to Pigovian taxes on carbon emitters as the efficient solution, currently the prevailing policy instruments in the US are mandates and tax-payer-funded subsidies for non-emitters. This brings about the question of how much emission can be attributable to renewable energy sources, where accurate calculations are key to the evaluation of the existing policies as well as informing future decision making.

Large-scale integration of these intermittent energy sources not only brings about technical challenges and potential cost increases but also raises concerns about the actual environmental efficacy of these sources. In this paper, we investigate the extent to which the intermittency in wind effects emissions from the electricity sector in ERCOT—a large grid system in the US with a high degree of wind penetration. For this, we use hourly and sub-hourly data from ERCOT and other sources recorded over the course of 13 years during which installed wind capacity increased by about seven folds. This allows us to observe the grid over a much wider range of wind generation interval than the existing studies.

We find that while wind generation has a clear negative effect on all emissions we studied, the effect of intermittency shows a large and irregular variation across different wind output levels. This implies that running such analyses with the pooled data can be misleading by masking this heterogeneity and can lead to inaccuracies in the emission savings estimates. Therefore, future studies estimating the environmental benefits of renewable energy need to do so at a higher granularity of wind output levels. 
Additionally, another notable observation throughout the estimation process is that model selection can be increasingly complex especially with a growing range of wind capacity. For this reason, although it is outside the scope of this paper, future work should certainly include state-of-the-art machine learning methods to estimate emissions savings with an increased level of granularity in the wind generation intervals. This seems to be the current frontier of many economic analyses as the datasets and the variety of variables observed grow conjointly with computational power and memory.

Finally, while the COVID-19 pandemic was not a prominent factor in energy use within the time period of our study, future work should expand this analysis to further study the impacts of the additional uncertainty that the pandemic has introduced into the system.

Author Contributions: Conceptualization, D.U.; methodology, D.U.; software, D.U. and C.C.; formal analysis, D.U. and C.C.; data curation, C.C.; writing-original draft preparation, D.U.; writingreview and editing, D.U. and C.C.; visualization, D.U.; supervision, D.U.; project administration, D.U. and C.C.; funding acquisition, C.C. All authors have read and agreed to the published version of the manuscript.

Funding: This research was funded in part by the Nevada Agricultural Experiment Station and UNR-UROP.

Data Availability Statement: The data presented in this study and all the code are available upon request from the corresponding author.

Acknowledgments: We would like thank three anonymous referees and Todd Sorensen for their helpful comments and suggestions. Any remaining errors are our own.

Conflicts of Interest: The authors declare no conflict of interest.

\section{References}

1. Wiser, R.; Bolinger, M.; Hoen, B.; Millstein, D.; Rand, J.; Barbose, G.; Darghouth, N.; Gorman, W.; Jeong, S.; Mills, A.; et al. Wind Energy Technology Data Update: 2020 Edition; Lawrence Berkeley National Laboratory: Washington, DC, USA, 2020.

2. Bistline, J.E.; Young, D.T. Economic drivers of wind and solar penetration in the US. Environ. Res. Lett. 2019, 14, 124001. [CrossRef]

3. Wind Explained: Electricity Generation from Wind. Available online: https://www.eia.gov/energyexplained/wind/electricitygeneration-from-wind.php (accessed on 25 July 2021).

4. Stehly, T.; Beiter, P.; Duffy, P. 2019 Cost of Wind Energy Review; Technical Report; National Renewable Energy Laboratory (NREL): Golden, CO, USA, 2020.

5. Global Greenhouse Gas Emissions Data. Available online: https://www.epa.gov/ghgemissions/global-greenhouse-gasemissions-data (accessed on 15 August 2021).

6. Liik, O.; Oidram, R.; Keel, M. Estimation of real emissions reduction caused by wind generators. In Proceedings of the International Energy Workshop, Laxenburg, Austria, 23 June 2003; pp. 24-26.

7. Dorsey-Palmateer, R. Effects of wind power intermittency on generation and emissions. Electr. J. 2019, 32, 25-30. [CrossRef]

8. Bushnell, J.B.; Wolfram, C. Ownership Change, Incentives and Plant Efficiency: The Divestiture of US Electric Generation Plants; 2005. CSEM Working Paper 140. Available online: https://www.haas.berkeley.edu/wp-content/uploads/csemwp140.pdf (accessed on 16 August 2021).

9. ERCOT Fact Sheet. Available online: https://www.ercot.com/files/docs/2020/11/10/ERCOT_Fact_Sheet_11.10.20.pdf (accessed on 16 August 2021).

10. Novan, K. Valuing the Wind: Renewable Energy Policies and Air Pollution Avoided. Am. Econ. J. Econ. Policy 2015, 7, 291-326. [CrossRef]

11. Pigou, A.C. The Economics of Welfare; Macmillan: Basingstoke, UK, 1924.

12. Baumol, W.J.; Baumol, W.J.; Oates, W.E.; Bawa, V.S.; Bawa, W.; Bradford, D.F.; Baumol, W.J. The Theory of Environmental Policy; Cambridge University Press: Cambridge, UK, 1988.

13. Renewable Portfolio Standards. Available online: https://www.nrel.gov/state-local-tribal/basics-portfolio-standards.html (accessed on 19 August 2021).

14. Renewable Energy Explained: Portfolio Standards. Available online: https:/ /www.eia.gov/energyexplained/renewable-sources / portfolio-standards.php (accessed on 20 August 2021).

15. Renewable Electricity Production Tax Credit Information. Available online: https://www.epa.gov/lmop/renewable-electricityproduction-tax-credit-information (accessed on 20 August 2021).

16. DeCarolis, J.F.; Keith, D.W. The economics of large-scale wind power in a carbon constrained world. Energy Policy 2006, 34, 395-410. [CrossRef] 
17. Newcomer, A.; Blumsack, S.A.; Apt, J.; Lave, L.B.; Morgan, M.G. Short run effects of a price on carbon dioxide emissions from US electric generators. Env. Sci. Tech. 2008, 42, 3139-3144. [CrossRef] [PubMed]

18. Van Kooten, G.C. Wind power: The economic impact of intermittency. Lett. Spat. Resour. Sci. 2010, 3, 1-17.

19. Gutiérrez-Martín, F.; Da Silva-Álvarez, R.; Montoro-Pintado, P. Effects of wind intermittency on reduction of $\mathrm{CO}_{2}$ emissions: The case of the Spanish power system. Energy 2013, 61, 108-117. [CrossRef]

20. Gowrisankaran, G.; Reynolds, S.S.; Samano, M. Intermittency and the value of renewable energy. J. Political Econ. 2016, 124, 1187-1234. [CrossRef]

21. Cullen, J. Measuring the Environmental Benefits of Wind-Generated Electricity. Econ. Policy 2013, 5, 107-133. [CrossRef]

22. Kaffine, D.T.; McBee, B.J.; Lieskovsky, J. Emissions Savings from Wind Power Generation in Texas. Energy J. $2013,34,155-175$. [CrossRef]

23. Callaway, D.S.; Fowlie, M.; McCormick, G. Location, Location, Location: The Variable Value of Renewable Energy and DemandSide Efficiency Resources. J. Assoc. Environ. Resour. Econ. 2018, 5, 39-75. [CrossRef]

24. Kaffine, D.T.; McBee, B.J.; Ericson, S.J. Intermittency and $\mathrm{CO}_{2}$ Reductions from Wind Energy. Energy J. 2020, 41, 23-54. [CrossRef]

25. Weisser, D. 05/01675 Instantaneous wind energy penetration in isolated electricity grids: Concepts and review. Fuel Energy Abstr. 2005, 501, 543 .

26. Albadi, M.; El-Saadany, E. Overview of wind power intermittency impacts on power systems. Electr. Power Syst. Res. 2010, 80, 627-632. [CrossRef] 